\title{
KAJIAN PENDUGAAN FUNGSI PRODUKSI USAHATANI PADI SAWAH DI KABUPATEN MUARO JAMBI PROVINSI JAMBI INDONESIA
}

\author{
Saidin Nainggolan, Saad Murdy dan Adlaida Malik. \\ Dosen Program Studi Agribisnis Faperta Universitas Jambi \\ Email: saidinnainggolan@yahoo.com
}

\begin{abstract}
ABSTRAK
Penelitian ini bertujuan untuk pendugaan fungsi produksi usahatani padi sawah di Kabupaten Muaro Jambi Provinsi Jambi. Pengambilan data menggunakan quisioner terhadap 60 petani yang dipilih secara acak sederhana. Pendugaan fungsi menggunakan Model fungsi produksi Cobb-Douglas, Model fungsi produksi transcendental, dan Model fungsi produksi inversi log-log. Hasil penelitian menunjukkan bahwa model fungsi terbaik yang mampu menggambarkan keadaan produksi usahatani padi sawah adalah model fungsi produksi Cobb-Douglas dengan nilai adj- $\mathrm{R}^{2}=0,8566$ [85,66 persen] untuk lahan lebak dan adj- $\mathrm{R}^{2}=0,8972$ [89,72 persen] untuk lahan pasang surut. Model fungsi produksi Cobb-Douglas dipilih sebagai fungsi terbaik karena menunjukkan nilai adj- ${ }^{2}$ tinggi dan Uji$\mathrm{t}$ masing-masing variabel penduga signifikan. Pada pendugaan fungsi produksi usahatani pada lahan pasang surut hanya model fungsi produksi Cobb-Douglas yang mampu menjelaskan hubungan teknis yang logis antara input produksi dengan produksi. Peningkatan produksi padi sawah lahan lebak akan meningkat dengan meningkatnya penggunaan luas lahan, benih, pupuk Urea, pupuk $\mathrm{KCl}$ dan tenaga kerja dalam keluarga. Pada lahan pasang surut peningkatan produksi jika meningkatnya penggunaan Urea. Penjumlahan semua parameter input produksi usahatani padi sawah pada lahan lebak diperoleh $\sum \beta_{i}=1.5428>1$. Hal ini berarti usahatani padi sawah lahan lebak berada pada daerah I (Increasing Return to Scale). Pada lahan pasang surut diperoleh $\sum \beta_{i}=1.7177>1$. Hal ini berarti usahatani padi sawah lahan pasang surut berada pada daerah I (Increasing Return to Scale). Efisiensi teknis kedua tipe lahan tergolong rendah yang berarti masih tersedia peluang besar untuk peningkatan produktivitas
\end{abstract}

\section{Kata Kunci : Pendugaan, Model, Fungsi Produksi, Padi Sawah}

\section{PENDAHULUAN}

Sub sektor tanaman pangan sebagai salah satu sub sektor pertanian merupakan penghasil komoditi bahan makanan. Kebutuhan masyarakat akan beras tidak pernah berkurang, akan tetapi terus meningkat sesuai dengan pertumbuhan penduduk yang merupakan faktor penentu tingkat permintaan beras. Sumaryanto (2009) mengatakan bahwa ketergantungan yang berlebihan terhadap satu jenis komoditas pangan, dalam hal ini beras, dapat berakibat rawan pangan. Dilain pihak laju peningkatan produksi padi dari periode ke periode bersifat stagnan. Salah satu penyebabnya adalah pelandaian produktivitas lahan sawah serta penggunaan input produksi yang tidak efisien pada usahatani padi sawah.

Provinsi Jambi merupakan salah satu provinsi di Indonesia dimana tanaman pangan banyak ditanami oleh masyarakat. Pembangunan tanaman pangan di Provinsi Jambi pada dasarnya merupakan suatu bagian yang tidak terpisahkan dari pembangunan pertanian di Indonesia. Pada tahun 2011 Provinsi Jambi memanfaatkan luas lahan sawah seluas $157.441 \mathrm{Ha}$, dengan tingkat produksi sebanyak 646.641 ton, dengan produktivitas $41,07 \mathrm{kw} / \mathrm{Ha}$. Sedangkan pada tahun 2015 , luas panen dan produksi turun drastis menjadi $122.214 \mathrm{Ha}$ dan 541.486 ton tetapi produktivitasnya meningkat menjadi 44,31 $\mathrm{kw} / \mathrm{Ha}$. Apabila dilihat dari perkembangan luas panen dan produksi selama kurun waktu lima tahun terakhir terjadi peningkatan luas panen sebesar 1,01 persen per tahun dan tingkat produksi sebesar 1,62 persen per tahun.

Utomo dan Nazarudin (1998) menyatakan bahwa dalam program peningkatan produksi padi, pemerintah masih tergantung kepada sawah sebagai tulang punggung pengadaan beras dibandingkan dengan lahan kering. Kondisi ini disebabkan oleh lahan sawah mempunyai produktivitas yang lebih tinggi dibandingkan dengan lahan kering. Dengan luas panen seluas 9.957 ha Kabupaten Muaro Jambi 
mampu menghasilkan gabah sebanyak 45.991 ton. Produksi gabah yang diberikan Kabupaten Muaro Jambi sebesar 8,3 persen dari total jumlah produksi gabah yang ada di Provinsi Jambi. Luas panen dan produktivitas padi sawah di Kabupaten Muaro Jambi relatif lebih kecil bila dibandingkan dengan kabupaten lain di Provinsi Jambi. Pada Tahun 2015 produktivitas padi mencapai 39,11 kw/Ha, hal ini masih lebih rendah jika dibandingkan daerah lain seperti Kabupaten Kerinci yang mampu mencapai produktivitas 56,16 kw/ha dan Kabupaten Batang Hari yang mampu mencapai produktivitas 49,49 $\mathrm{kw} / \mathrm{ha}$. Hal ini menunjukkan bahwa usahatani padi di Kabupaten Muaro Jambi masih dapat ditingkatkan. Rendahnya produktivitas di Kabupaten Muaro Jambi diduga karena belum optimalnya penggunaan input produksi dalam usahatani padi sawah.

Usahatani padi sawah pada lahan lebak dan pada lahan pasang surut diusahakan sekali dalam setahun dengan pola tanam padi-palawija (kedelai dan jagung). Dengan pengugunaan benih varietas unggul (Ciherang dan Inpara) sebanyak $30 \mathrm{~kg} / \mathrm{ha}$ dan rata-rata penggunaan pupuk urea $100 \mathrm{~kg} / \mathrm{ha}$, SP $3650 \mathrm{~kg} / \mathrm{ha}$ serta KCl $50 \mathrm{~kg} / \mathrm{ha}$. Produktivitas pada lahan lebak hanya mampu mencapai 3 - 4 ton/ha. Hal ini sejalan dengan penelitian yang dilakukan oleh Nasamsir (2010) tentang "Identifikasi Keragaan Teknologi Usahatani Padi Sawah Lahan Rawa Lebak di Kabupaten Muaro Jambi" hasil penelitian menunjukkan bahwa rata-rata produksi padi pada lahan lebak mencapai 2,5-3,0 ton/ha.

Selain kondisi lahan, tinggi rendahnya produksi tidak terlepas dari peran petani dalam mengalokasikan berbagai input produksi yang digunakan. Apabila penggunaan input produksi tidak tepat waktu dan tepat jumlahnya maka dapat menimbulkan pemborosan sehingga penggunaan input produksi menjadi tidak efisien. Penggunaan input produksi seperti lahan, benih, pupuk, obat-obatan, tenaga kerja, dan sebagainya akan mempengaruhi besar kecilnya produksi yang diperoleh. Semakin banyak input produksi yang digunakan maka produksi akan semakin tinggi atau bahkan rendah (Daniel, 2004). Dengan adanya kombinasi yang efisien antara satu input produksi dengan input produksi yang lainnya diharapkan mampu memberikan produksi yang tinggi. Karena itu perlu dilakukan "Analisis Pendugaan Fungsi Produksi Usahatani Padi Sawah di Kabupaten Muaro Jambi Provinsi Jambi”.

\section{METODE PENELITIAN}

Penelitian ini dilakukan di Kabupaten Muaro Jambi dengan lokus penelitian di Kecamatan Kumpeh yang mempunyai kondisi lahan lebak dan pasang surut. Penelitian ini dilakukan pada dua desa yaitu Desa Mekar Sari mewakili lahan lebak, dan Desa Sungai Aur mewakili lahan pasang surut. Ukuran sampel ditentukan secara purposive sebanyak 60 petani dengan rincian 30 petani dari masingmasing desa sampel. Pengambilan sampel dilakukan dengan Simple Random Sampling Method dengan menggunakan tabel bilangan random.

Untuk mengetahui faktor-faktor yang mempengaruhi produksi digunakan model fungsi produksi Cobb-Douglas, Transcedental dan Inversi log-log dengan menggunakan metode Ordinary Least Square (OLS). Adapun model fungsi produksi (Soekartawi, 1994) dapat dirumuskan sebagai berikut:

1. Model fungsi produksi Cobb-Douglas

$\mathrm{Y}=\mathrm{A} \prod_{i}^{n} X i^{\beta \mathrm{B}}$

Dalam penelitian ini model ditransformasikan menjadi:

$\log Y=\log A+\beta_{1} \log X_{1}+\beta_{2} \log X_{2}+\beta_{3} \log X_{3}+\beta_{4} \log X_{4}+\beta_{5} \log X_{5}+\beta_{6} \log X_{6}+\beta_{7} \log X_{7}+\beta_{8} \log X_{8}+$

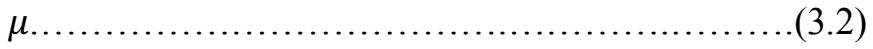

2. Model fungsi produksi transcendental

$\mathrm{Y}=\mathrm{A} \prod_{i=1}^{n} x i^{\beta i} \mathrm{e}^{\mathrm{\alpha ixi}}$

Dalam penelitian ini model ditransformasikan menjadi:

$\log Y=\log A+\beta_{1} \log X_{1}+\beta_{2} \log X_{2}+\beta_{3} \log X_{3}+\beta_{4} \log X_{4}+\beta_{5} \log X_{5}+\beta_{6} \log X_{6}+\beta_{7} \log X_{7}+\beta_{8} \log X_{8}+$

$\alpha_{1} \mathrm{X}_{1+} \alpha_{2} \mathrm{X}_{2}+\alpha_{3} \mathrm{X}_{3}+\alpha_{4} \mathrm{X}_{4}+\alpha_{5} \mathrm{X}_{5}+\alpha_{6} \mathrm{X}_{6}+\alpha_{7} \mathrm{X}_{7}+\alpha_{8} \mathrm{X}_{8}+\mu+$ ...(3.4)

3. Model fungsi produksi inversi log-log 
$\mathrm{Y}=\mathrm{A} \prod_{i=1}^{n} x i^{\beta \mathrm{i}} \mathrm{e}^{\alpha \mathrm{i} / \mathrm{xi}}$

Dalam penelitian ini model ditransformasikan menjadi:

$\log Y=\log A+\beta_{1} \log X_{1}+\beta_{2} \log X_{2}+\beta_{3} \log X_{3}+\beta_{4} \log X_{4}+\beta_{5} \log X_{5}+\beta_{6} \log X_{6}+\beta_{7} \log X_{7}+\beta_{8} \log X_{8}+$ $\alpha_{1} \mathrm{X}_{1}^{-1}+\alpha_{2} \mathrm{X}_{2}^{-1}+\alpha_{3} \mathrm{X}_{3}^{-1}+\alpha_{4} \mathrm{X}_{4}^{-1}+\alpha_{5} \mathrm{X}_{5}^{-1}+\alpha_{6} \mathrm{X}_{6}^{-1}+\alpha_{7} \mathrm{X}_{7}^{-1}+\alpha_{8} \mathrm{X}_{8}^{-1}+\mu$

Keterangan:

$\mathrm{Y}=$ Jumlah total produksi padi $(\mathrm{kg})$

$\mathrm{X}_{1}=$ Luas lahan usahatani padi sawah (ha)

$\mathrm{X}_{2}=$ Jumlah benih padi $(\mathrm{kg})$

$\mathrm{X}_{3}=$ Pupuk $\mathrm{N}(\mathrm{kg})$

$\mathrm{X}_{4}=$ Pupuk P $(\mathrm{kg})$

$\mathrm{X}_{5}=$ Pupuk K $(\mathrm{kg})$

$\mathrm{X}_{6}=$ Penggunaan obat-obatan (liter)

$\mathrm{X}_{7}=$ Tenaga kerja dalam keluarga (HOK)

$\mathrm{X}_{8}=$ Tenaga kerja luar keluarga $(\mathrm{HOK})$

$\mathrm{A}=$ Konstanta

$\beta_{\mathrm{i}}=$ Koefisien Regresi $; \mathrm{i}=1,2,3, \ldots 8$

$\alpha_{\mathrm{i}}=$ Koefisien Regresi; $i=1,2,3, \ldots 8$

$\mu=$ Kesalahan Pengganggu

\section{HASIL DAN PEMBAHASAN}

\section{Kondisi Riil Penggunaan Input produksi di Daerah Penelitian}

Luas lahan berkisar 0,20-1,30 ha, rata-rata 0,90 ha dengan koefisien variasi 25,7 persen untuk usahatani padi lahan lebak, untuk usahatani padang surut luas lahan berkisar 0,25-1,85 ha, rata-rata 1,30 ha dengan koefisien variasi 26,5 persen, penggunaan benih berkisar $15-25 \mathrm{~kg}$, rata-rata $17,0 \mathrm{~kg}$ koefisien variasi 15,5 persen untuk lahan lebak, untuk lahan pasang surut penggunaan benih berkisar $20-40 \mathrm{~kg}$, rata-rata $25,0 \mathrm{~kg}$ dengan koefisien variasi 22,5 persen.

Penggunaan pupuk, urea 20-70 kg, SP36 15-30 kg, dan KCl 15-30 kg. Penggunaan pupuk ini hanya 40,5 persen; 25 persen dan 15,0 persen dari curahan untuk usahatani padi lahan lebak, untuk lahan pasang surut; urea $18-75 \mathrm{~kg}$; SP36 20-50 kg dan $\mathrm{KCl} 17,5-30 \mathrm{~kg}$. Penggunaan pupuk ini hanya 38,6persen, 22,3persen dan 15,7persen dari anjuran. Penggunaan tenaga kerja dalam keluarga sebanyak 25-50 HOK, rata-rata 35,0 HOK; koefisien variasi 20,1 persen; tenaga kerja luar keluarga sebanyak 20-35 HOK; rata-rata 28,2 HOK dan koefisien variasi 17,5 persen untuk usahatani lahan lebak, pada usahatani pasang surut penggunaan tenaga kerja luar keluarga sebanyak 30-70 HOK; ratarata 46,8 HOK; koefisien variasi 20,5 persen; tenaga kerja luar keluarga sebanyak 15-40 HOK; ratarata 25,0 HOK dengan koefisien variasi 15.5

\section{Pendugaan Fungsi Produksi}

Hasil uji-F disajikan dalam tabel varian fungsi produksi usahatani padi sawah lahan lebak dengan ketiga pendekatan model fungsi produksi disajikan Tabel 1 berikiut

Tabel 1 menunjukkan hasil uji F-hitung yang tertinggi untuk model pada fungsi Transcendental F-hitung sebesar 81,622 Hasil uji F-hitung untuk ketiga model fungsi memperlihatkan bahwa secara statistik variasi penggunaan input produksi secara bersama-sama berpengaruh terhadap variasi produksi padi. Hal ini berarti ketiga model fungsi produksi layak digunakan dalam pendugaan fungsi produksi usahatani padi sawah.

Tabel 1. Varian Fungsi Produksi Usahatani Padi Sawah Pada Lahan Lebak di Daerah Penelitian Tahun 2017

\begin{tabular}{lcccccc}
\hline Model Fungsi & SS & SE & DF & MS & F hitung & Prob F hitung \\
\hline Cobb-Douglas & 1.704 & 0,028 & 8 & 0,322 & 72,453 & 0.00206 \\
Transcendental & 1,723 & 0,022 & 16 & 0,135 & 81,622 & 0.00311 \\
Inversi Log-log & 1,736 & 0,015 & 16 & 0,135 & 75,640 & 0.00257 \\
\hline
\end{tabular}


Hasil pendugaan parameter fungsi produksi usahatani padi sawah lahan lebak dengan ketiga pendekatan fungsi produksi dapat dilihat Tabel 2 berikut :

Tabel 2. Hasil Pendugaan Parameter Tiga Fungsi Produksi Usahatani Padi Lahan Lebak di Daerah Penelitian Tahun 2017

\begin{tabular}{lccccc}
\hline \multirow{2}{*}{ Variabel } & \multicolumn{5}{c}{ Fungsi Produksi } \\
\cline { 2 - 6 } & Cobb-Douglas & \multicolumn{2}{c}{ Transcendental } & \multicolumn{2}{c}{ Inversi Log-log } \\
\cline { 2 - 6 } & $\beta_{\mathrm{i}}$ & $\beta_{\mathrm{i}}$ & $\alpha_{\mathrm{i}}$ & $\beta_{\mathrm{i}}$ & $\alpha_{\mathrm{i}}$ \\
\hline Lahan $\left(\mathrm{X}_{1}\right)$ & $0,9876^{\mathrm{a}}$ & 0.8447 & 0.2255 & $1.5548^{\mathrm{b}}$ & 0.0854 \\
Benih $\left(\mathrm{X}_{2}\right)$ & $0,2135^{\mathrm{a}}$ & -0.1435 & 0.0066 & 0.0072 & 0.2155 \\
Urea $\left(\mathrm{X}_{3}\right)$ & $0.1670^{\mathrm{b}}$ & $1.3452^{\mathrm{a}}$ & $-0.0972^{\mathrm{a}}$ & $0,8975^{\mathrm{a}}$ & $-1.7581^{\mathrm{a}}$ \\
SP 36 $\left(\mathrm{X}_{4}\right)$ & 0.0078 & 0.0085 & 0.0002 & 0.0315 & 0.0025 \\
KCl $\left(\mathrm{X}_{5}\right)$ & $0.0256^{\mathrm{a}}$ & $0.0283^{\mathrm{b}}$ & 0.0005 & 0.0152 & -0.0076 \\
Obat $\left(\mathrm{X}_{6}\right)$ & 0.0972 & 0.1976 & 0.0344 & 0.3128 & 1.1083 \\
TKDK $\left(\mathrm{X}_{7}\right)$ & $0.3246^{\mathrm{b}}$ & $0.8850^{\mathrm{c}}$ & $-0.0083^{\mathrm{c}}$ & 0.4021 & $-6,2433$ \\
TKLK $\left(\mathrm{X}_{8}\right)$ & 0.1465 & 0.3125 & 0.0018 & 0.1756 & $-2,4947$ \\
\hline Konstanta & 1.6245 & \multicolumn{3}{c}{0.0975} & \multicolumn{2}{c}{0.8355} \\
\hline Adj- $\mathrm{R}^{2}$ & 0.8972 & \multicolumn{2}{c}{0.9035} & \multicolumn{2}{c}{0.8247} \\
\hline Kerang
\end{tabular}

Keterangan: a,b,c signifikan pada taraf 0.01, 0,05, dan 0,10

Tabel 2 menunjukkan bahwa parameter hasil pendugaan yang mengahasilkan $\mathrm{R}^{2}$ terkoreksi adalah model fungsi produksi Inversi Log-log dengan adj- $\mathrm{R}^{2}=0.8247$, Transcendental dengan adj- $\mathrm{R}^{2}$ $=0.9035$ dan Cobb-Douglas dengan adj- $\mathrm{R}^{2}=0.8972$. Untuk ketiga jenis fungsi produksi menunjukkan bahwa Urea termasuk faktor penentu pada taraf 95 persen. Meskipun fungsi transcendental memperlihatkan adj- $\mathrm{R}^{2}$ yang tinggi namun, Uji-t masing-masing variabel penjelas menunjukkan beda nyata pada fungsi Cobb-Douglas. Sehingga model fungsi produksi yang sesuai dalam usahatani padi sawah pada lahan lebak di daerah penelitian adalah model fungsi produksi Cobb-Douglas.

Dari penjumlahan semua nilai parameter dari variabel peubah Tabel 2 diperoleh $\sum \beta_{\mathrm{i}}=1,5428$ lebih besar dari 1 (satu). Hal ini memperlihatkan bahwa usahatani padi sawah pada lahan lebak berada pada daerah produksi tahap I (Increasing Return to Scale) atau sedang mengalami skala usaha yang semakin bertambah dan belum efisien secara teknik. Dengan demikian peningkatan penggunaan masukan (input) sebesar 10 persen akan meningkatkan produksi (output) sebesar 15,428 persen.

Hasil uji-F varian fungsi produksi usahatani padi sawah lahan pasang surut dengan ketiga pendekatan model fungsi produksi dapat dilihat tabel 3 berikut:

Tabel 3. Varian Fungsi Produksi Usahatani Padi Lahan Pasang Surut di Daerah Penelitian Tahun 2017

\begin{tabular}{lcccccc}
\hline Model Fungsi & SS & SE & DF & MS & F hitung & Prob F hitung \\
\hline Cobb-Douglas & 2,544 & 0,058 & 8 & 0,318 & 33.856 & 0.000655 \\
Transcendental & 2,532 & 0,045 & 15 & 0,169 & 29,525 & 0.000872 \\
Inversi Log-log & 2,615 & 0,056 & 15 & 0,174 & 27.329 & 0.000962 \\
\hline
\end{tabular}

Tabel 3 menunjukkan hasil uji F-hitung untuk setiap model yang diuji. Pada fungsi CobbDouglas memperlihatkan F-hitung sebesar 63,44556, pada fungsi Transcendental F-hitung sebesar 53,83258 dan pada fungsi Inversi Log-log F-hitung sebesar 46,51646. Hasil uji F-hitung yang tinggi untuk ketiga model fungsi memperlihatkan bahwa secara statistik variasi penggunaan input produksi secara bersama-sama berpengaruh terhadap variasi produksi padi. Hal ini berarti ketiga model fungsi produksi layak digunakan dalam pendugaan fungsi produksi usahatani padi lahan pasang surut.

Hasil pendugaan parameter fungsi produksi usahatasni padi sawah pada lahan pasang surut dengan ketiga pendekatan fungsi produksi dapat dilihat Tabel 4 berikut.

Tabel 4. Hasil Pendugaan Parameter Tiga Fungsi Produksi Usahatani Padi Lahan Pasang Surut di Daerah Penelitian Tahun 2017 


\begin{tabular}{|c|c|c|c|c|c|}
\hline \multirow{3}{*}{ Variabel } & \multicolumn{5}{|c|}{ Fungsi Produksi } \\
\hline & \multirow{2}{*}{$\frac{\text { Cobb-Douglas }}{\beta_{\mathrm{i}}}$} & \multicolumn{2}{|c|}{ Transcendental } & \multicolumn{2}{|c|}{ Inversi Log-log } \\
\hline & & $\beta_{\mathrm{i}}$ & $\alpha_{i}$ & $\beta_{\mathrm{i}}$ & $\alpha_{i}$ \\
\hline $\operatorname{Lahan}\left(\mathrm{X}_{1}\right)$ & $1.1755^{\mathrm{a}}$ & $-5.3227^{\mathrm{a}}$ & $8.4261^{\mathrm{a}}$ & $6.3282^{\mathrm{b}}$ & $4.3262^{\mathrm{b}}$ \\
\hline $\operatorname{Benih}\left(\mathrm{X}_{2}\right)$ & $-0.7912^{\mathrm{a}}$ & $-3.2885^{\mathrm{a}}$ & $-0.1982^{\mathrm{a}}$ & $-2.4365^{b}$ & $-3.4085^{b}$ \\
\hline Urea $\left(\mathrm{X}_{3}\right)$ & $0.7838^{\mathrm{a}}$ & -0.0124 & 0.0043 & 1.8201 & 3.6820 \\
\hline SP $36\left(X_{4}\right)$ & $0.1834^{\mathrm{c}}$ & -0.0236 & 0.0828 & 0.1705 & 0.0076 \\
\hline $\mathrm{KCl}\left(\mathrm{X}_{5}\right)$ & 0.0933 & 0.2031 & -0.03825 & 0.1176 & 0.0042 \\
\hline Obat $\left(\mathrm{X}_{6}\right)$ & 0,0239 & 0.0883 & -0.3012 & 0.0623 & -0.1365 \\
\hline $\operatorname{TKDK}\left(\mathrm{X}_{7}\right)$ & $0.1135^{\mathrm{c}}$ & $0.9765^{\mathrm{b}}$ & $-0.0435^{\mathrm{b}}$ & $-2.3201^{\mathrm{c}}$ & $-8.3620^{\mathrm{c}}$ \\
\hline $\operatorname{TKLK}\left(\mathrm{X}_{8}\right)$ & $0.1333^{\mathrm{c}}$ & $0.8234^{\mathrm{b}}$ & $-0.6320^{\mathrm{b}}$ & -1.8366 & -4.8360 \\
\hline Konstanta & 1.2544 & \multicolumn{2}{|c|}{-77.06528} & \multicolumn{2}{|c|}{68.448788} \\
\hline Adj-R ${ }^{2}$ & 0.8566 & \multicolumn{2}{|c|}{0.966831} & \multicolumn{2}{|c|}{0.961704} \\
\hline
\end{tabular}

Keterangan: a,b,c signifikan pada taraf 0.01, 0,05, dan 0,10

Tabel 4 menunjukkan bahwa parameter hasil pendugaan yang mengahasilkan $\mathrm{R}^{2}$ terkoreksi tertinggi adalah model fungsi produksi Transcendental dengan adj- $\mathrm{R}^{2}=0.9668$, Inversi Log-log dengan adj- $\mathrm{R}^{2}=0.9617$ dan Cobb-Douglas dengan adj- $\mathrm{R}^{2}=0.8566$. Meskipun model fungsi transcendental dan inversi log-log memberikan nilai adj- $\mathrm{R}^{2}$ yang lebih tinggi namun bentuk aljabar fungsi produksi tersebut tidak dapat dipertanggungjawabkan karena tidak mampu menjelaskan hubungan ekonomi yang logis antara input produksi dengan produksi. Sehingga model fungsi terbaik dan benar yang mampu menggambarkan usahatani padi sawah pada lahan pasang surut di daerah penelitian adalah model fungsi produksi Cobb-Douglas.

Dari penjumlahan semua nilai parameter dari variabel peubah $\sum \beta_{i}=1,7177$ lebih besar dari 1 (satu) yang artinya usahatani padi sawah pada lahan pasang surut berada pada daerah produksi tahap I (Increasing Return to Scale). Hal ini berarti peningkatan penggunaan masukan (input) sebesar 10 persen mampu meningkatkan produksi (output) sebesar 17,177 persen. Dengan kata lain bahwa usahatani padi sawah pada lahan pasang surut sedang mengalami skala penambahan hasil yang semakin bertambah.

Pendugaan fungsi produksi usahatani padi lahan lebak dan lahan pasang surut memperlihatkan bahwa model fungsi yang paling sesuai adalah model fungsi produksi Cobb-Douglas, sehingga dalam analisis pendugaan fungsi produksi gabungan tanpa dummy dan dengan dummy dilakukan pendugaan dengan pendekatan fungsi produksi Cobb-Douglas. Varian fungsi usahatani padi sawah dengan pendekatan model fungsi produksi Cobb-Douglas disajikan dalam Tabel 5 berikut:

Tabel 5. Varian Fungsi Usahatani Padi Dengan Pendekatan Fungsi Produksi Cobb-Douglas di Daerah Penelitian Tahun 2017

\begin{tabular}{lcccccc}
\hline Usahatani & SS & SE & DF & MS & F hitung & Prob F hit \\
\hline Lahan Lebak & 1,603 & 0,023 & 8 & 0,200 & 72,4333 & 0.00000 \\
$\begin{array}{l}\text { Lahan Pasang Surut } \\
\text { Gabungan Tanpa }\end{array}$ & 1,242 & 0,049 & 8 & 1,55 & 63.44556 & 0.00000 \\
$\begin{array}{l}\text { Dummy } \\
\text { Gabungan Dengan }\end{array}$ & 3,262 & 0,075 & 8 & 0,408 & 71.45033 & 0.00000 \\
Dummy & 3,336 & 0,066 & 9 & 0,371 & 82.71817 & 0.00000 \\
\hline
\end{tabular}

Tabel 5 menunjukkan bahwa F-hitung untuk pendugaan masing-masing usahatani padi sawah di daerah penelitian tinggi dan signifikan. Pada usahatani padi sawah lahan lebak F-hitung sebesar 72,433 , hal ini menunjukkan bahwa secara statistik variasi penggunaan input produksi secara bersamasama berpengaruh terhadap variasi produksi padi lahan lebak di daerah penelitian. Pada usahatani padi sawah pada laha pasang surut F-hitung sebesar 63.44556 yang menunjukkan bahwa secara statistik variasi penggunaan input produksi secara bersama-sama berpengaruh terhadap variasi produksi padi lahan pasang surut di daerah penelitian.

Pada usahatani padi sawah gabungan tanpa dummy atau tanpa membedakan jenis lahan yang diusahakan petani sampel memperlihatkan F-hitung sebesar 71.45033, hal ini berarti secara statistik variasi penggunaan input produksi secara bersama-sama berpengaruh terhadap variasi produksi padi. 
Demikian pula pada usahatani padi sawah gabungan dengan dummy meperlihatkan F-hitung sebesar 82.71817, hal ini berarti secara statistik variasi penggunaan input produksi secara bersama-sama berpengaruh terhadap variasi produksi padi di daerah penelitian.

Hasil pendugaan parameter fungsi produksi terhadap fungsi produksi usahatani padi sawah pada lahan lebak, usahatani padi sawah pada lahan pasang surut, gabungan tanpa dummy dan gabungan dengan dummy dengan pendekatan model fungsi produksi Cobb-Douglas disajikan dalam Tabel 6 berikut:

Tabel 6. Hasil Pendugaan Parameter Fungsi Produksi Usahatani Padi Dengan Pendekatan Model Fungsi Produksi Cobb-Douglas di Daerah Penelitian Tahun 2017

\begin{tabular}{lcccc}
\hline Variabel Input & Lebak & Pasang Surut & $\begin{array}{c}\text { Gabungan tanpa } \\
\text { Dummy }\end{array}$ & $\begin{array}{c}\text { Gabungan } \\
\text { dengan Dummy }\end{array}$ \\
\hline Lahan $\left(\mathrm{X}_{1}\right)$ & $0,9876^{\mathrm{a}}$ & $1.1755^{\mathrm{a}}$ & 0.4036 & 0.3561 \\
Benih $\left(\mathrm{X}_{2}\right)$ & $0,2135^{\mathrm{a}}$ & $0.7912^{\mathrm{a}}$ & $-0.5361^{\mathrm{a}}$ & 0.6365 \\
Urea $\left(\mathrm{X}_{3}\right)$ & $0.1670^{\mathrm{b}}$ & $0.7838^{\mathrm{a}}$ & $1.8305^{\mathrm{a}}$ & $1.9850^{\mathrm{a}}$ \\
SP 36 $\left(\mathrm{X}_{4}\right)$ & 0.0078 & $0.1834^{\mathrm{c}}$ & -0.0819 & $-0.1285^{\mathrm{b}}$ \\
KCl $\left(\mathrm{X}_{5}\right)$ & $0.0256^{\mathrm{a}}$ & 0.0933 & -0.0819 & 0.1855 \\
Obat $\left(\mathrm{X}_{6}\right)$ & 0.0972 & 0,0239 & 0.0185 & $0.1435^{\mathrm{b}}$ \\
TKDK $\left(\mathrm{X}_{7}\right)$ & $0.3246^{\mathrm{b}}$ & $0.1135^{\mathrm{c}}$ & $0.1530^{\mathrm{a}}$ & $0.7610^{\mathrm{a}}$ \\
TKLK $\left(\mathrm{X}_{8}\right)$ & 0.1465 & $0.1333^{\mathrm{c}}$ & $0.6776^{\mathrm{c}}$ & 0.8533 \\
\multicolumn{1}{c}{$\mathrm{D} 1$} & 1.6245 & 1.2544 & 0.4312 & $0.4819^{\mathrm{a}}$ \\
\hline \multicolumn{1}{c}{ Konstanta } & 0.8972 & 0.8566 & 1.454692 & 1.358011 \\
\hline Adj-R ${ }^{2}$ & $0,9876^{\mathrm{a}}$ & $1.1755^{\mathrm{a}}$ & 0.905237 & 0.925736 \\
\hline
\end{tabular}

Keterangan: a,b,c signifikan pada taraf 0.01, 0,05, dan 0,10

Tabel 6 menunjukkan hasil pendugaan parameter fungsi produksi gabungan tanpa dummy dengan pendekatan model fungsi produksi Cobb-Douglas menunjukkan adj- $\mathrm{R}^{2}=0.9052$, hal ini berarti 90,52 persen variasi produksi dapat dijelaskan oleh input produksi. Sedangkan sisanya dijelaskan oleh faktor lain yang tidak masuk ke dalam model analisis.

Variabel benih $\left(\mathrm{X}_{2}\right)$, Urea $\left(\mathrm{X}_{3}\right)$, tenaga kerja dalam keluarga $\left(\mathrm{X}_{7}\right)$ berpengaruh nyata pada taraf 99 persen dengan tanda positif kecuali pada variabel benih berpengaruh nyata dengan tanda yang negatif. Tenaga kerja luar keluarga $\left(\mathrm{X}_{8}\right)$ berpengaruh nyata pada taraf 90 persen dengan tanda positif.

Variabel luas lahan $\left(\mathrm{X}_{1}\right)$ berpengaruh dengan positif terhadap produksi padi sawah. Variabel ini mempunyai nilai elastisitas sebesar 0,4036. Hal ini berarti apabila luas lahan yang diusahakan ditambah sebesar 10 persen maka akan meningkatkan produksi sebesar 4,036 persen, dengan asumsi kondisi penggunaan input lainnya dianggap konstan. Hal ini sejalan dengan hasil penelitian yang dilakukan oleh Nainggolan (2011) bahwa luas lahan berpengaruh sangat nyata terhadap produksi padi Kabupaten Kerinci dengan nilai elastisitas sebesar 0,716, luas lahan merupakan faktor utama dalam upaya peningkatan produksi padi.

Pendugaan parameter variabel benih $\left(\mathrm{X}_{2}\right)$ berpengaruh nyata dengan tanda negatif terhadap produksi padi sawah. Nilai elastisitas sebesar 0,5361 , hal ini berarti penambahan penggunaan jumlah benih sebesar 10 persen akan menurunkan produksi sebesar 5,361 persen, dengan asumsi penggunaan input lainnya konstan. Penggunaan pupuk Urea $\left(\mathrm{X}_{3}\right)$ akan meningkatkan produksi dengan nilai elastisitas sebesar 1,8505, hal ini berarti penambahan penggunaan pupuk Urea sebesar 10 persen akan meningkatkan produksi sebesar 18,505 persen.

Pendugaan parameter variabel SP $36\left(\mathrm{X}_{4}\right)$ dan $\mathrm{KCl}\left(\mathrm{X}_{5}\right)$ berpengaruh nyata dengan tanda negatif. Hal ini menunjukkan bahwa penambahan penggunaan SP 36 dan $\mathrm{KCl}$ akan menurun produksi padi di daerah penelitian. Variabel SP 36 dengan nilai elastisitas sebesar 0,0819. Hal ini berarti penambahan penggunaan SP 36 sebesar 10 persen akan menurunkan produksi sebesar 0,819 persen. Demikian pula pada Variabel $\mathrm{KCl}$ dengan nilai elastisitas sebesar 0,0819 maka penambahan penggunaan $\mathrm{KCl}$ sebesar 10 persen akan menurunkan produksi sebesar 0,819 persen dengan asumsi penggunaan input lainnya dianggap konstan. 
Penggunaan obat-obatan $\left(\mathrm{X}_{6}\right)$ akan memberikan pengaruh nyata pada peningkatan produksi padi. Hal ini ditunjukkan oleh besarnya nilai elastisitasnya sebesar 0,0185 dengan tanda positif. Artinya penambahan penggunaan obat-obatan sebesar 10 persen akan diikuti oleh peningkatan produksi padi sebesar 0.185 persen. Demikian pula dengan penambahan tenaga kerja dalam keluarga $\left(\mathrm{X}_{7}\right)$ dan tenaga kerja luar keluar $\left(\mathrm{X}_{8}\right)$ akan meningkatkan produksi padi sawah. Dengan nilai elastisitas sebesar 0,6776 dan 0,4312 maka penambahan penggunaan tenaga kerja dalam keluarga dan tenaga kerja luar keluarga sebesar 10 persen akan meningkatkan produksi secara berturut-turut sebesar 6,776 persen dan 4,312 persen dengan asumsi penggunaan input yang lain konstan.

Pada pendugaan fungsi produksi gabungan tanpa dummy nilai $\sum \beta_{i}=2,8145$. Hal ini berarti secara teknik usahatani padi di daerah penelitian sedang mengalami skala usaha yang semakin bertambah dan belum efisien secara teknik, dimana peningkatan penggunaan masukan (input) sebesar 10 persen akan meningkatkan produksi (output) sebesar 28,145 persen.

Model fungsi produksi padi sawah gabungan dengan dummy di daerah penelitian menunjukkan bahwa fungsi produksi terbentuk cukup baik dengan besarnya adj- $\mathrm{R}^{2}=0,9257$. Hasil pendugaan ini menunjukkan bahwa keragaman produksi padi sawah di daerah penelitian dapat dijelaskan oleh keragaman variabel independen sebesar 92,57 persen. Variabel-variabel yang berpengaruh nyata terhadap produksi rata-rata adalah pupuk Urea $\left(\mathrm{X}_{3}\right)$, obat-obatan $\left(\mathrm{X}_{6}\right)$ dan tenaga kerja dalam keluarga $\left(\mathrm{X}_{7}\right)$ pada taraf 99 persen dengan tanda positif. Sedangkan variabel pupuk SP $36\left(\mathrm{X}_{4}\right)$ berpengaruh nyata pada taraf 95 persen dengan tanda negatif dan variabel dummy $\left(\mathrm{D}_{1}\right)$ berpengaruh nyata pada taraf 99 persen dengan tanda positif.

Variabel luas lahan $\left(\mathrm{X}_{1}\right)$ berpengaruh dengan positif terhadap produksi padi sawah. Variabel ini mempunyai nilai elastisitas sebesar 0,3561. Hal ini berarti apabila luas lahan yang diusahakan ditambah sebesar 10 persen maka akan meningkatkan produksi sebesar 3.561 persen, dengan asumsi kondisi pengunaan input lainnya dianggap konstan. Variabel benih $\left(\mathrm{X}_{2}\right)$ berpengaruh nyata dan bertanda positif dengan nilai elastisitas 0.6365 . Hal ini berarti penambahan penggunaan benih sebesar 10 persen akan meningktakan produksi sebesar 6,365 persen dengan asumsi kondisi variabel input yang lain konstan. Hal ini sejalan dengan penelitian yang dilakukan oleh Nainggolan (2011), bahwa penggunaan benih berpengaruh nyata pada produksi padi dengan niali elastisitas sebesar 0,125 dengan tanda positif, yang artinya penambahan penggunaan benih akan meningkatkan produksi padi dengan asumsi faktor lain dianggap konstan.

Penambahan penggunaan pupuk Urea $\left(\mathrm{X}_{3}\right)$ akan meningkatkan produksi dengan elastisitas sebesar 1,9850. Hal ini berarti penambahan penggunaan pupuk Urea sebesar 10 persen akan meningkatkan produksi sebesar 19,850 persen dengan asumsi kondisi penggunaan input yang lain dianggap konstan. Pupuk SP $36\left(\mathrm{X}_{4}\right)$ berpengaruh nyata dengan tanda negatif. Nilai elastisitas penggunaan pupuk SP 36 sebesar 0,1285, artinya penambahan penggunaan pupuk SP 36 sebesar 10 persen akan menurunkan produksi sebesar 1,285 persen. Pada penggunaan pupuk $\mathrm{KCl}\left(\mathrm{X}_{5}\right)$, pupuk $\mathrm{KCl}$ memiliki nilai elastisitas sebesar 0,1855 . Sehingga penambahan penggunaan pupuk $\mathrm{KCl}$ dan tenaga kerja dalam keluarga sebesar 10 persen akan meningkatkan produksi sebesar 1,855 persen. Dengan asumsi bahwa penggunaan input lainnya dianggap konstan.

Parameter pendugaan variabel obat-obatan $\left(\mathrm{X}_{6}\right)$, tenaga kerja dalam keluarga $\left(\mathrm{X}_{7}\right)$ dan tenaga kerja luar keluarga $\left(\mathrm{X}_{8}\right)$ memperlihatkan tanda positif yang artinya penambahan penggunaan obatobatan dan tenaga kerja akan meningkatkan produksi padi. Variabel obat-obatan $\left(\mathrm{X}_{6}\right)$ memperlihatkan nilai elastisitas sebesar 0,1435 . Artinya penambahan penggunaan obat-obatan sebesar 10 persen akan meningkatkan produksi padi sebesar 1,435 persen dengan asumsi faktor lain dianggap konstan. Penggunaan tenaga kerja dalam keluarga $\left(\mathrm{X}_{7}\right)$ dan tenaga kerja luar keluarga $\left(\mathrm{X}_{8}\right)$ dengan nilai elastisitas masing-masing sebesar 0,7610 dan 0,4810 . Hal ini berarti peningkatan penggunaan tenaga kerja sebesar 10 persen akan meningktakan produksi padi sebesar 7,610 persen dan 4,810 persen. Hal ini sejalan dengan penelitian yang dilakukan oleh Nainggolan (2011) yang menunjukkan bahwa tenaga kerja berpengaruh nyata terhadap peningkatan produksi padi di Kabupaten Kerinci dengan nilai elastisitas sebesar 0,1032. Penelitian yang dilakukan oleh Ahmad (2004) menunjukkan bahwa penggunaan tenaga kerja berpengaruh nyata pada taraf 85 persen terhadap peningkatan produksi padi dengan nilai elastisitas sebesar 1,087.

Pada pendugaan fungsi produksi gabungan dengan dummy nilai $\sum \beta_{\mathrm{i}}=5,2743$ lebih besar dari 1 (satu). Hal ini berarti usahatani padi sawah di daerah penelitian sedang mengalami skala usaha yang 
semakin bertambah dan secara teknik usahatani padi sawah di daerah penelitian juga belum efisien, dimana peningkatan penggunaan masukan (input) sebesar 10 persen akan meningkatkan produksi (output) sebesar 52,743 persen.

\section{Tingkat Efisiensi Teknis Usahatani Padi Sawah}

Pendugaan tingkat efisiensi teknis usahatani padi sawah dapat dilihat Tabel 7 berikut:

Tabel 7. Tingkat Efisiensi Usahatani Padi Sawah di Daerah Penelitian Tahun 2017

\begin{tabular}{lccc}
\hline \multicolumn{1}{c}{ Usahatani } & Produksi Aktual $(\overline{\mathbf{Y}})$ & $\begin{array}{c}\text { Dugaan Produksi } \\
\text { Potensial }\left(Y_{\text {Pot }}\right)\end{array}$ & $\mathrm{E}_{\mathrm{T}}$ \\
\hline Lahan Lebak & 3895,80 & 6536.90 & 0.5960 \\
Lahan Pasang Surut & 2935,65 & 5540.75 & 0.5298 \\
Gabungan tanpa Dummy & 3466,60 & 5870,45 & 0.5905 \\
Gabungan dengan Dummy & 3475.72 & 6375.72 & 0.5451 \\
\hline
\end{tabular}

Tabel 7 menunjukkan bahwa tingkat efisiensi teknis usahatani padi sawah tergolong rendah. Tingkat efisiensi teknis suatu usahatani dikatakan efisien apabila mendekati frontier (TE-1) dan besarnya TE $>0,70$ (Nainggolan, 2011). Tingkat efisiensi teknis yang rendah mencerminkan keterampilan manajerial petani cukup rendah. Tingkat efisiensi teknik yang rendah berarti peluang untuk meningkatkan produktivitasnya semakin besar karena selisih produktivitas yang telah dicapai dengan produktivitas maksimum yang mungkin dicapai sangat besar.

Nilai efisiensi teknis usahatani padi sawah pada lahan lebak sebesar 59,60 persen hal ini berarti peluang untuk meningkatkan produktivitas sebesar 40,4 persen dengan cara mengoptimumkan penggunaan input produksi usahatani padi lahan lebak. Penelitian yang dilakukan oleh Suslinawati (2010) tentang "Pengukuran Efisiensi Teknis Pada Usahatani Padi Di lahan Lebak Pematang, Kalimantan Selatan" menunjukkan bahwa nilai rata-rata TE yang dicapai sebesar 0.8918 dengan nilai TE terendah sebesar 0.7708 dan nilai TE tertinggi mencapai 0.9698 , hal ini berarti semua petani relatif mencapai nilai maksimum TE. Angka efisiensi 89,18 persen memberi makna bahwa rata-rata petani dapat mencapai paaling tidak 89 persen dari potensial produksi yang diperoleh dari kombinasi masukan produksi yang dikorbankan dan peluang untuk meningkatkan produksi padi sebesar 11 persen.

Pada usahatani padi lahan pasang surut nilai efisiensi teknis sebesar 52,98 persen dan peluang untuk meningkatkan produktivitas sebesar 47,02 persen dengan penggunaan input produksi yang optimal. Selebihnya dibutuhkan inovasi teknologi baru dalam meningkatkan produktivitas usahatani di daerah penelitian. Menurut penelitian yang dilakukan oleh Ahmad (2010) tentang "Faktor-Faktor Yang Mempengaruhi Efisiensi Teknis Pada Usahatani Padi Lahan Pasang Surut Di Kecamatan Anjir Muara Kabupaten Barito Kuala Kalimantan Selatan" memperlihatkan bahwa rata-rata petani di lokasi penelitian telah efisien secara teknis dengan rata-rata efisiensi teknis mencapai 0.920 dan faktor yang berpengaruh terhadap efisiensi teknis adalah umur petani dan pendidikan petani, namun pengaruhnya tidak signifikan.

Jika dilihat dari usahatani gabungan, nilai efisiensi teknis pada usahatani padi sawah di daerah penelitian tanpa membedakan jenis lahan yang diusahakan maka tingkat efisiensi usahatani padi sawah sebesar 59,05 persen. Sedangkan tingkat efisiensi teknis dengan membedakan jenis lahan yang diusahakan petani sebesar 54,51 persen.

\section{KESIMPULAN DAN SARAN}

\section{Kesimpulan}

1. Model fungsi terbaik yang mampu menggambarkan keadaan produksi usahatani padi sawah adalah model fungsi produksi Cobb-Douglas dengan nilai adj- $\mathrm{R}^{2}=0,8566$ [85,66 persen] untuk lahan lebak dan adj- $\mathrm{R}^{2}=0,8972$ [89,72 persen] untuk lahan pasang surut. Model fungsi produksi Cobb-Douglas dipilih sebagai fungsi terbaik karena menunjukkan nilai adj- $\mathrm{R}^{2}$ tinggi dan Uji-t masing-masing variabel penduga signifikan. Pada pendugaan fungsi produksi usahatani pada 
lahan pasang surut hanya model fungsi produksi Cobb-Douglas yang mampu menjelaskan hubungan ekonomi yang logis antara input produksi dengan produksi.

2. Peningkatan produksi padi sawah pada lahan lebak akan meningkat dengan meningkatnya penggunaan luas lahan, benih, pupuk Urea, pupuk $\mathrm{KCl}$ dan tenaga kerja dalam keluarga. Pada lahan pasang surut peningkatan produksi jika meningkatnya penggunaan Urea.

3. Penjumlahan semua parameter input produksi usahatani padi sawah pada lahan lebak diperoleh $\sum \beta_{\mathrm{i}}=1.5428>1$. Hal ini berarti usahatani padi sawah lahan lebak berada pada daerah II yang artinya sedang mengalami skala penambahan hasil yang semakin bertambah. Pada lahan pasang surut diperoleh $\sum \beta_{\mathrm{i}}=1.7177$ juga lebih besar dari 1 . Hal ini berarti usahatani padi sawah lahan pasang surut berada pada daerah II dan sedang mengalami skala penambahan hasil yang semakin bertambah.

\section{Saran}

1. Untuk meningkatkan efisiensi teknis usahatani padi sawah maka perlu menggunakan input produksi secara proporsional dengan memperhatikan hasil pendugaan parameter.

2. Peningkatan produktivitas dengan inovasi teknologi melalui pendekatan Pengelolaan Terpadu yang meliputi pengelolaan (penataan) air, penggunaan benih dengan varietas yang adaptif dan berkualitas, pemupukan berimbang, dan pengendalian hama penyakit terpadu.

\section{DAFTAR PUSTAKA}

Badan Pusat Statistik. 2013. Produk Domestik Bruto Menurut Lapangan Usaha Tahun 2012. Badan Pusat Statistik Indonesia. From : http://www.bps.go.id (Diakses Februari 2014)

Daniel, Moehar. 2004. Pengantar Ekonomi Pertanian. Bumi Aksara. Jakarta.

Gustini, Eni. 2001. Pemilihan Fungsi Produksi Pucuk Teh di PT Perkebunan Nusantara (PTPN) VIII Jawa Barat. Institut Pertanian Bogor. From : http://repository.ipb.ac.id. (Diakses April 2014).

Nainggolan, Saidin. 2011. Pengaruh Program Penguatan Modal Petani Terhadap Pendapatan dan Efisiensi Usahatani Padi Sawah di Kabupaten Tanjung Jabung Barat Provinsi Jambi. Universitas Jambi

Nasamsir. 2010. Identifikasi Keragaan Teknologi Usahatani Padi Sawah Lahan Rawa Lebak di Kabupaten Muaro Jambi. Jurnal Universitas Batang Hari. From: http://journal.unbari.ac.id. (Diakses Mei 2014).

Rina dan Aidi. 2008. Prospek Pengembangan Lahan Rawa Sebagai Sumber Produksi Padi Di Kalimantan Selatan. BPTP Kalsel. From: http://kalsel.litbang.deptan.go.id. (Diakses Mei 2014).

Soekartawi. 1994. Teori Ekonomi Produksi Dengan Pokok Bahasan Analisis Fungsi Cobb-Douglas. PT. Raja Grafindo Persada. Jakarta. 
Sudana, Wayan. 2004. Potensi dan Prospek Lahan Rawa Sebagai Sumber Produksi Pertanian. Jurnal Analisis Kebijakan Pertanian. Volume 3 No.2. 2005. From: pangan.litbang.deptan.go.id. (Diakses Mei 2014).

Suslinawati. 2010. Pendugaan Fungsi Produksi Usahatani Padi Lahan Pasang Surut (Kasus Pada Sentra Yang Berpotensi Terdampak Oleh Perubahan Iklim. Jurnal Media Sains, Volume 3 No.1. 2011. (Diakses Februari 2014).

Sumaryanto. 2009. Diversifikasi Sebagai Salah Satu Pilar Ketahanan Pangan. Pusat Analisis Sosial Ekonomi dan Kebijakan Pertanian. Bogor.

Utomo, M dan Nazarudin. 1998. Bertanam Padi Sawah Tanpa Olah Tanah. Penebar Swadaya. Jakarta. 